\title{
Resistance of Nineteen Major Caladium Commercial Cultivars to Pythium Root Rot ${ }^{1}$
}

\author{
Z. Deng, B.K. Harbaugh, R.O. Kelly, T. Seijo, and R. J. McGovern²
}

Caladiums (Caladium xhortulanum) are popular ornamental plants widely grown for their bright colorful leaves. Pythium root rot, caused by $P$. myriotylum, is one of the few soil-borne diseases in caladium that can dramatically reduce plant growth, aesthetic value, and tuber yield. Identification and use of disease-resistant cultivars has proven to be an important and economically viable strategy for integrated management of major diseases in crops and for reducing the use of pesticides. This strategy will be particularly useful for caladiums in the landscape and home gardens, because in such cases choices of root rot control measures are limited. However, information on the resistance level of commercial caladium cultivars has been lacking.

\section{Pythium Isolates}

Three $P$. myriotylum isolates, $97-439 \mathrm{~B}, \mathrm{P} 1$, and $\mathrm{P} 2$, were collected from rotting roots of field- or greenhouse-grown plants, and their pathogenecity was tested on three cultivars, 'Florida Elise', 'Florida Fantasy' and 'Florida Red Ruffles'. All three isolates were found to be pathogenic and very aggressive on caladium roots. When tissue-culture-derived plants of these cultivars were inoculated with Pythium oogonia at a density of 10,000 per $\mathrm{mL}$, root rotting and lesions appeared within 3 days after inoculation. By the 10th day after inoculation, $30-75 \%$ of the roots rotted. Rotting continued to develop on roots from 10 to 17 days after the inoculation, but at a much slower rate. After this period of time, the majority of the roots were rotted. Difference in the mycelial growth rate was noticeable among the isolates, but no significant differences were observed among them in inducing root rot on the three cultivars.

\section{Resistance Evaluation}

Two experiments were conducted to evaluate the resistance level of 19 major commercially grown cultivars (Table 1). The majority of these cultivars are among the top 15 grown by the caladium tuber producers and greenhouse growers, and they may represent the best genetic resources in $C$.

xhortulanum in terms of horticultural characteristics and performance. The resistance evaluation was based on artificial inoculation of tissue-culture-derived plants with Pythium oogonia followed by visual assessment of tissue rotting on

1. This document is ENH996, one of a series of the Environmental Horticulture Department, Florida Cooperative Extension Service, Institute of Food and Agricultural Sciences, University of Florida. Original publication date December 2, 2004. Visit the EDIS Web Site at http://edis.ifas.ufl.edu.

2. Z. Deng, assistant professor, B.K. Harbaugh, professor, R.O. Kelly, research coordinator, Gulf Coast Research and Education Center, Bradenton; T. Seijo, senior biological scientist, Gulf Coast Research and Education Center Dover; and R.J. McGovern, director and professor, Doctor of Plant Medicine Degree Program, Florida Cooperative Extension Service, IFAS, University of Florida, Gainesville, FL 32611.

The Institute of Food and Agricultural Sciences (IFAS) is an Equal Employment Opportunity - Affirmative Action Employer authorized to provide research, educational information and other services only to individuals and institutions that function without regard to race, creed, color, religion, age, disability, sex, sexual orientation, marital status, national origin, political opinions or affiliations. For information on obtaining other extension publications, contact your county Cooperative Extension Service office. Florida Cooperative Extension Service / Institute of Food and Agricultural Sciences / University of Florida / Larry R. Arrington, Interim Dean 
roots. The tissue culture plants were initially derived from shoot tips of caladium buds on tubers, and they were grown in 6-pack plastic cells (each with a volume of $67 \mathrm{ml}$ ) in greenhouses. When plants were approximately 8 weeks old and 6 to 12 inches tall, with 3 to 6 leaves, they were inoculated with Pythium oogonia. Five $\mathrm{mL}$ of an oogonium suspension, from the above three isolates and adjusted to 1,000 6,000 oogonia per $\mathrm{mL}$, were applied to the root media (vermiculite, $\sim 50 \mathrm{~mL}$ in volume) surface of each plant. Control plants each received $5 \mathrm{~mL}$ of sterile water to their root media. To promote root rot after inoculation, continuous moisture saturation of the root media and warm day and night temperatures $\left(90-99^{\circ} \mathrm{F}\right.$ and $\left.79-82^{\circ} \mathrm{F}\right)$ were provided. Ten days after inoculation, root rotting and plant leaf losses were visually rated for each plant on a scale of 1 to 5 . For the root rot rating: $1=100 \%, 1.5=95-99 \%, 2=$ $85-94 \%, 2.5=84-55 \%, 3=35-54 \%, 3.5=15-34 \%, 4$ $=5-14 \%, 4.5=1-4 \%$ of root tissue on the root ball surface rotted, and 5=all root tissue appeared healthy without any rotting compared to the control plants. To help categorize the levels of root rot resistance, the following scale was also used: $>=4.5$ : resistant; $<4.5$ but $>=4$ : moderately resistant $; 4$ but $>=3$ : susceptible; and <3: very susceptible. The scale for rating plant leaf losses was: $1=$ all leaves wilted or lost; $2=$ most $(>50 \%)$ leaves wilted or lost; $3=$ some leaves wilted $(\sim 30 \%)$ and showing chlorosis; $4=$ almost normal, but showing chlorosis and some stunting; and 5=all leaves growing normally, compared to the control plants. After evaluation, re-isolations of Pythium were made from representative roots of rotted plants to verify the presence of the causal disease agent. The 19 cultivars showed similar levels of resistance in both experiments and their data were averaged and shown in Table 1.

\section{Cultivar Differences}

The majority of the cultivars (15 out of 19) were susceptible or highly susceptible to Pythium root rot. Within 10 days after inoculation, seven cultivars, 'Fannie Munson', 'Gingerland', 'Gray Ghost', 'Red Flash', 'Red Frill', 'Texas Beauty', and 'White Queen', had 35\% to 94\% of their root tissue rotted and a rating of 2.9 to 2.1. Eight cultivars, 'Aaron', 'Carolyn Whorton', 'Florida Elise', 'Florida
Fantasy', 'Florida Red Ruffles', 'Florida

Sweetheart', 'Miss Muffet', and 'Pink Beauty' lost $15 \%$ to $35 \%$ of their roots to rotting and had a rating of 3.8 to 3.0. 'Red Frill' seems to be extremely susceptible to Pythium root rot; it lost more than $85 \%$ of its roots to rotting by 10 days after inoculation. Four cultivars, 'Candidum', 'Candidum Jr.', 'Frieda Hemple', and 'White Christmas' had a moderate level of resistance to Pythium root rot. Plants of these cultivars had only $5-14 \%$ of their roots rotted by the 10th day after inoculation (Fig. 1).

These plants were maintained for an extended period (6-7 weeks after inoculation) and were able to maintain a rating of 2.1 to 2.9 for root rot and leaf losses and kept 10 to $50 \%$ of their roots healthy. Control plants for each cultivar did not show signs of rotting during the 10 day period of evaluation.

In addition to reddish lesions and rotting on roots, several leaf symptoms appeared soon after inoculation. These symptoms included tan, necrotic blotches on leaves, especially along leaf edges, yellowing on entire leaves, epinastic petioles, and leaf wilting, collapse and losses (defoliation) (Fig. 2).

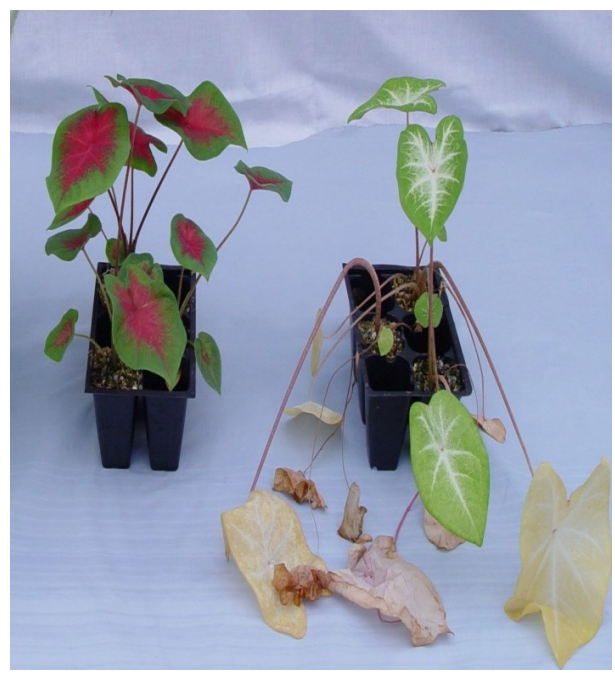

Fig. 2. Plant leaf losses on 'Gray Ghost' (GG), as compared to normal leaf growth on 'Frieda Hemple' (FH), 13 days after inoculation.

These symptoms occurred as early as 3 days after inoculation and became more severe 7 days after inoculation. When a rating of plant leaf losses was made on a scale of 1 to 5, leaf losses were highly correlated to the severity of root rotting. Regression analysis showed a linear relationship between plant 
leaf loss and root rot severity. The four cultivars that had a moderate level of resistance to root rot maintained an average leaf loss rating of 4.0, while the eight susceptible and the seven very susceptible cultivars maintained an average leaf loss rating 3.4, and 2.8 , respectively (Table 1 ).

\section{Literature Cited}

Hartman, R.D. 1974. Dasheen mosaic virus and other phytopathogens eliminated from caladium, taro, and cocoyam by culture of shoot tips.

Phytopathology 64:237-240.

Ridings, W.H. and R.D. Hartman. 1976.

Pathogenicity of Pythium myriotylum and other species of Pythium to caladium derived from shoot-tip culture. Phytopathology 66:704-709. 
Table 1. Resistance levels of 19 major commercial caladium cultivars to Pythium.

\begin{tabular}{|c|c|c|c|c|c|}
\hline Cultivar & $\begin{array}{l}\text { Leaf } \\
\text { shape }\end{array}$ & $\begin{array}{l}\text { Impact } \\
\text { color }\end{array}$ & $\begin{array}{l}\text { Root rotting } \\
\text { rating }\end{array}$ & $\begin{array}{l}\text { Root rot } \\
\text { resistance }\end{array}$ & $\begin{array}{c}\text { Plant leaf } \\
\text { loss } \\
\text { rating }\end{array}$ \\
\hline Frieda Hemple & Fancy & Red & 4.4 & MR & 4.2 \\
\hline Candidum & Fancy & White & 4.3 & MR & 4.0 \\
\hline Candidum Jr. & Fancy & White & 4.0 & MR & 4.0 \\
\hline White Christmas & Fancy & White & 4.0 & MR & 3.8 \\
\hline Carolyn Whorton & Fancy & Pink & 3.8 & $S$ & 4.0 \\
\hline Florida Fantasy & Fancy & Multicolor & 3.4 & S & 3.3 \\
\hline Florida Elise & Fancy & Pink & 3.3 & S & 2.9 \\
\hline Florida Red Ruffles & Lance & Red & 3.3 & $S$ & 3.6 \\
\hline Florida Sweetheart & Lance & Pink & 3.2 & $S$ & 3.6 \\
\hline Aaron & Fancy & White & 3.2 & $S$ & 3.3 \\
\hline Miss Muffet & Fancy & Multicolor & 3.0 & $S$ & 3.3 \\
\hline Pink Beauty & Fancy & Pink & 3.0 & $S$ & 3.2 \\
\hline Red Flash & Fancy & Red & 2.9 & VS & 2.9 \\
\hline Fannie Munson & Fancy & Pink & 2.8 & VS & 2.9 \\
\hline Gingerland & Fancy & Multicolor & 2.8 & VS & 3.1 \\
\hline Gray Ghost & Fancy & White & 2.8 & VS & 2.7 \\
\hline White Queen & Fancy & Multicolor & 2.8 & VS & 3.1 \\
\hline Texas Beauty & Fancy & Red & 2.6 & VS & 2.6 \\
\hline Red Frill & Strap & Red & 2.1 & VS & 2.5 \\
\hline
\end{tabular}

